\title{
Resource Potential of One of Earth's Final Remaining Frontiers: The Siberian Platform
}

Benedikt M. Steiner ${ }^{1}$ and James S.K. Barnet ${ }^{2}$

1 Camborne School of Mines, University of Exeter, Penryn TR10 9FE, United Kingdom; B.Steiner@exeter.ac.uk

2 School of Earth and Environmental Sciences, University of St Andrews, Irvine Building, North Street, St Andrews KY16 9AL, United Kingdom; isb24@standrews.ac.uk

\begin{abstract}
The Siberian Platform, covering a vast area of East Siberia (Russian Federation), represents one of the largest underexplored regions in Asia. Previous expeditions and regional surveys in the $20^{\text {th }}$ Century, however, suggest that the Siberian Platform and adjacent orogenic belts hold significant potential for large undiscovered gold, copper, diamond and industrial mineral deposits, along with extensive oil and gas fields. The remoteness of the region, inhospitable winter climate, and major lack of modern infrastructure and mining methods, have long hampered exploration in this area. These factors, along with the additional investment required and political uncertainties involved with operating in Russia, have deterred many international mining companies from considering the Siberian Platform as a viable region for exploration and mining. However, as mining industry paradigms change into a green, battery metals-driven commodity sector, and modern mining methods are developed, increasing efficiency at a lower cost, the significant undiscovered mineral potential of the Siberian Platform could elevate the region to the forefront of mineral exploration and mining in the future.
\end{abstract}

\section{Location and Regional Setting}

The Siberian Platform comprises a significant portion of the Siberian Craton, extending from the Yenisey River in the west to the late Mesozoic Verkhoyansk Fold Belt in the east (Figure 1). In the south, the Siberian Platform is bordered by a chain of PaleozoicMesozoic fold belts resulting from a long history of continental accretion, including the Baikal-Patom Fold Belt in the south-west and the Stanovoy Fold Belt in the south-east. The Late Paleozoic Taimyr Fold Belt forms the northern border of the platform. The Siberian Platform separates the prolific oil and gas fields of the West Siberian Basin from the Russian Far East. The term "platform" is used throughout the literature, highlighting the evolution of the Siberian Craton from a marine, carbonate and evaporite-dominated platformal shelf in the Late Neoproterozoic and Early Paleozoic, to more terrestrially influenced clastic marine and continental environments from the Middle-Late Paleozoic onwards, as mountain ranges rose around the periphery of the platform. 


\section{History of Geological Research, Metallogeny and Mineral Deposits}

Early geological and exploratory work of the Siberian Platform dates back to the early 1930s when researchers from the Geological Survey/Ministry of Geology and Mineral Resources of the SSSR and the Russian Academy of Sciences (RAS) conducted systematic regional work across East Siberia, establishing the first regional stratigraphic subdivision of the Precambrian and Paleozoic. In-depth geological work was not conducted until the late 1940s-1950s, when oil and gas discoveries in the Vilyuy Depression and Nepa-Botuoba Arch, along with gold discoveries in the Magadan District, encouraged the Soviet government to explore for additional mineral and energy resources in East Siberia. At this time, regional studies primarily focused on the stratigraphy, palaeontology and distribution of depositional environments across the Siberian Platform. Mining efforts primarily used forced labour to access remote areas comprising hardrock and alluvial mineral deposits, for example along the Kolyma 'Highway' connecting the settlements of Yakutsk and Magadan. More recent tectono-stratigraphic work comprises structural interpretations based on the acquisition of regional 2D seismic data, deep drilling, and regional basin screening studies conducted by governmental agencies and private companies. Regional basin screening studies were furthermore conducted by the United States Geological Survey (USGS) in the 2000s, leading to a synthesis of geological information and knowledge.

In terms of accessing geological information and data, by far the most significant challenge to Western geologists is the lack of English literature accessible on the Siberian Platform, and Russian geology in general. Detailed historic information and data collected and processed over the last eight decades are largely available in Russian language and in archives only. Nevertheless, scientific publications in Western journals are becoming more common, and regional compilations have been made available by the United States Geological Survey (USGS), Cambridge Arctic Shelf Programme (CASP), and other individuals (Barnet and Steiner, this issue; Steiner and Barnet, 2017).

\section{Mineral Resources of the Siberian Platform}

Nowadays, the principle motivation for exploring the vast territories of the Siberian Platform is based on its potentially significant undiscovered hydrocarbon and mineral resources. The Siberian Platform is host to a plethora of metallic and industrial mineral occurrences and deposits. Whilst metallic mineral deposits are mainly located on Precambrian basement uplifts and around the margins of the platform, related to a long history of Neoproterozoic and Phanerozoic continental accretion, industrial minerals are found predominantly in the Phanerozoic sedimentary cover sequence of the Siberian Platform interior.

Over the last five decades, a number of metallogenic districts have been outlined and are summarised here on a commodity by commodity basis (Figure 2): 
Diamonds are found in the Vilyuy, Olenek, Muna and Aldan regions and are hosted both in secondary, alluvial deposits and in primary Permian-Jurassic kimberlite pipes, similar in nature to the South African Kimberley fields.

Gold occurrences and deposits are present as (1) 'orogenic' quartz-sulphide-gold vein/stockwork mineralisation in carbonaceous (meta)sediments of the Northern Baikal mineralised belt (Patom Highlands), (2) 'orogenic' disseminated gold-sulphide mineralisation hosted in carbonate-mica schists of the Yenisey Range (e.g., Olimpiada - Polyus Gold), and (3) porphyry Au-(Cu) and epithermal Au of the Central Aldan Ore District (e.g., Lebediny, Kuranakh). Gold occurs both in primary and alluvial deposits facilitating prospecting and exploration of secondary dispersion trends.

Stratiform copper deposits hosted in quartz-carbonate sandstones in the Kalar District of the Zabaikalye Region (Udokan - Baikal Mining Company).

Norilsk-type Nickel-Copper-Platinum Group Element deposits are located on the north-western flank of the Siberian platform around the world-famous Norilsk mining camp. Mineralisation is commonly related to sub-volcanic intrusions of the PermianTriassic Siberian Traps (volcanic flood basalts).

Coal (thermal and lignite) is concentrated in Carboniferous, Permian, Jurassic, Early Cretaceous and Neogene formations of the: i.) Tunguska, ii.) Irkutsk, iii.) Baikal Rift, iv.) Lena, v.) Vilyuy, and vi.) South Yakutian (Aldan) coalfields. These coalfields have a much larger resource base than any other Russian coal basin, however inaccessibility has to date limited the development of these resources. The coal occurrences and mining districts play an important role in industrialisation and export to other Asian countries. It is not uncommon that new towns and settlements are established to facilitate the development of new coal and metal mines. For example, Neryungri, one of the youngest towns/cities in Russia, was only established in 1975, due to the discovery of tens of billions of tons of coking coal in the 1960s.

Potash, rock salt and gypsum deposits are intrinsically related to extensive late Neoproterozoic to Cambrian halite and gypsum sequences up to several hundred metres thick, deposited across the central and southern portions of the Siberian Platform. These deposits make this region one of the most prospective areas for evaporitic industrial minerals in Asia and across the world. Deposits are related to platformal sedimentation from 550-500 Ma, extending from the upper reaches of the Angara River to the Lena River area, as well as diapiric salt domes (Kempendyay, Kygyl-Tus, Kyundai) piercing through overlying Mesozoic sedimentary cover in the Vilyuy Depression. The highest quality and thickest deposits were formed in restricted sub-basins across the southern part of the Siberian Platform, where there was sufficient accommodation space for the development of thick halite beds. Diapiric salt domes of Devonian age are also found along the northern margin of the Siberian Platform around Port Nordvik on the Laptev Sea coast. 


\section{Current major exploration and development projects}

Lacking a developed infrastructure in East Siberia, minerals were historically produced for local use only. Exploration success continued after the end of the SSSR and further prospective deposits were delineated. An example is the Sukhoi Log gold deposit in the Baikal-Patom region (Irkutsk Oblast), discovered in 1961, which was explored in the 1970s and currently proceeds through feasibility studies by operator Polyus Gold and Russian state conglomerate Roster. A large resource base of $962 \mathrm{Mt}$ at $2.1 \mathrm{~g} / \mathrm{t}$ gold (63 Moz of contained gold) was outlined in 2018. Similarly, Kopy Goldfields AB, Orsu Metals and Nordgold are currently working on a number of gold development projects with the aim of bringing these into production in the near future.

Siberia displays great potential for additional metallic and industrial mineral discoveries, as most areas are still unchartered in terms of modern exploration techniques and have received limited attention in terms of foreign investment. Regions of primary interest are focused across the Norilsk, Aldan Shield, Baikal-Patom, Verkhoyansk, and Krasnoyarsk/Yenisey Range regions. However, mineral companies still face operating and administrative challenges, including long winters, remote and undeveloped infrastructure in parts of East Siberia, and obtaining mineral extraction licenses through technical audits of resource estimates by the State.

\section{Hydrocarbon resources of the Siberian Platform}

In the early 1930s, oil was first discovered in Cambrian dolomites on the western Siberian Platform and since then the search for oil and gas has continued. Most oil and gas fields on the Siberian Platform are concentrated on two large-scale horst-type "arches" ("anteclises" in Russian nomenclature) or "high" structures: the NepaBotuoba and Baykit High Provinces (Figure 1). Famous large discoveries have been made in Precambrian-Cambrian sandstones and carbonates, such as the Markovo Field on the Nepa-Botuoba Arch (1962) and the Yurubchen-Tokhomo Zone on the Kamov Arch (early 1980s), which represents a smaller regional structure on the Baykit High. Of particular scientific interest is the occurrence of a number of Middle-Late Riphean (1300 Ma-650 Ma) source rocks comprising carbonaceous shale, deposited in a dysoxic, restricted marine setting (Figure 3). Along with source rocks of the Nafun Group (Oman Basin), the Riphean rocks of the Siberian Platform represent one of the oldest sources of hydrocarbons in the world, given that most hydrocarbon-prone basins formed during the Mesozoic and Tertiary. In fact, these discoveries were the first and only commercial Proterozoic-Early Paleozoic oil and gas fields outlined in Asia, and are therefore of particular interest to Russian petroleum geologists.

The Vilyuy Depression in the east of the Siberian Platform has also attracted significant interest for hydrocarbon exploration, although only gas has been discovered in economic quantities. The first gas field (the Ust' Vilyuy) came online in 1968, and since then a further 9 gas fields have been discovered. Most of the current gas production takes place along the crest of the Khapchagay Arch, a WSW-ENE 
trending uplift extending through the central part of the Vilyuy Depression to the western margin of the Cis-Verkhoyansk Foredeep, with some production from the smaller SW-NE trending Loglor Arch in the west. Most of the fields have been discovered at the crests of anticline structures, along with pinchout of reservoir formations at the western basin margin. Gas production (such as in the Ust' Vilyuy Field) has also taken place from frontal thrusts along the western margin of the CisVerkhoyansk Foredeep, however the eastern part of the Foredeep and the Verkhoyansk Range are generally considered unprospective due to likely leakage of generated hydrocarbons and a general eastward decrease in reservoir quality. The potential for oil production has been highlighted especially along the north-western margin of the basin, where numerous oil shows have been discovered.

The principal source rocks charging the gas fields of the Vilyuy Depression are Late Permian coals and coaly continental shales (Figure 4). Highest concentrations of Type III gas-prone kerogen are found in the purely terrestrial sediments in the west of the basin on the Khapchagay Arch, where the TOC in coaly continental shales averages $3.4 \%$. These continental sediments, deposited under a warm and humid climate favourable for the proliferation of land plants, were deposited on a vast coastal plain and have been penetrated by wells in many parts of the Vilyuy Depression. Early Jurassic (Toarcian) marine organic-rich shales of the Suntar Formation were deposited throughout the basin and may have reached oil maturity in the basin centre, potentially sourcing oil seeps discovered along the western basin margin. The main producing reservoir formations are Late Permian-Early Triassic continental and shallow marine sandstones, sealed by overlying marine shales deposited during maximum Early Triassic marine transgression (Figure 4).

Other parts of the Siberian Platform which are considered prospective for hydrocarbons include the Yenisey-Khatanga Basin, Lena-Anabar Basin and offshore on the Laptev Shelf to the north of the Siberian Platform, where exploration is ongoing.

\section{Conclusions}

The Siberian Platform and adjacent mountain ranges represent one of the last exploration frontiers in the World. Research into the geological development of the area, along with industrial mineral exploration and the search for new deposits, will shape the decades to come. Unravelling this complex terrain will require not only significant financial means, but also a multi-disciplinary team consisting of geologists, biostratigraphers, geophysicists, mineralogists, geochemists and logistics professionals.

\section{Suggested reading}

Frolov, S.V., Akhmanov, G.G., Kozlova, E.V., Krylov, O.V., Sitar, K.A. \& Galushkin, Y.I. 2011. Riphean basins of the central and western Siberian Platform. Marine and Petroleum Geology, v.28(4), 906-920. 
Nalivkin, D.V., 1973. The Geology of the U.S.S.R. University of Toronto Press, 855p.

Nokleberg, W.J. (Ed.) 2010. Metallogenesis and tectonics of northeast Asia. USGS Professional Paper 1765, 624p.

Steiner, B.M. \& Barnet, J.S.K. 2017. Petroleum potential of the southern and eastern Siberian Platform, Russia: An evaluation of proven petroleum systems and directions for future exploration. XPLORE.GLOBAL, Exploration Targeting Series, 2, 77p. [online]

Ulmishek, G.F. 2001. Petroleum Geology and Resources of the Nepa-Botuoba High, AngaraLena Terrace, and Cis-Patom Foredeep, Southeastern Siberian Craton, Russia. USGS Bulletin 2201-C, 19p. 
Figures

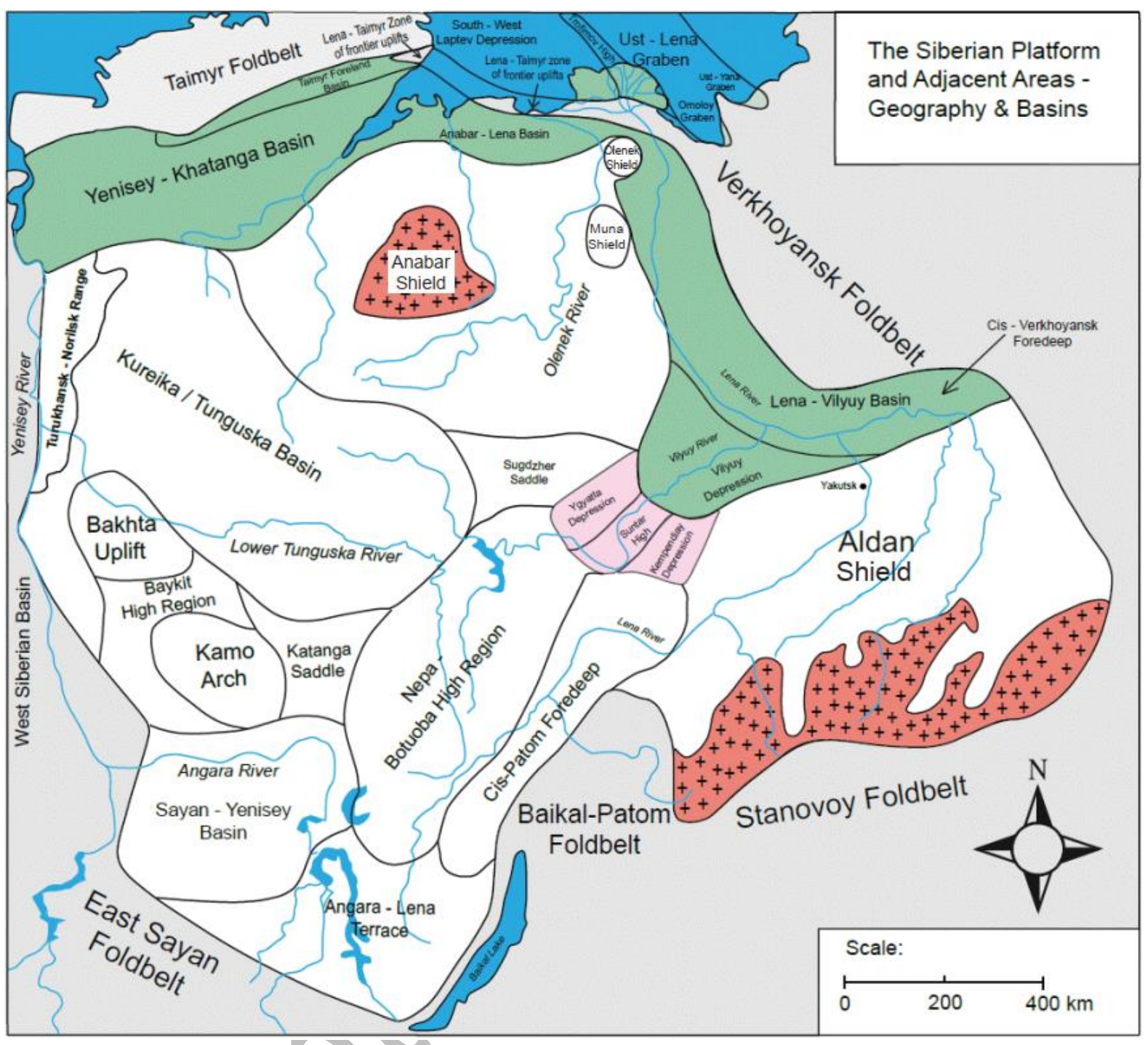

Figure 1. Overview of the basins and highs of the Siberian Platform, East Siberia (Source: Steiner \& Barnet, 2017; modified from Frolov et al., 2011). 


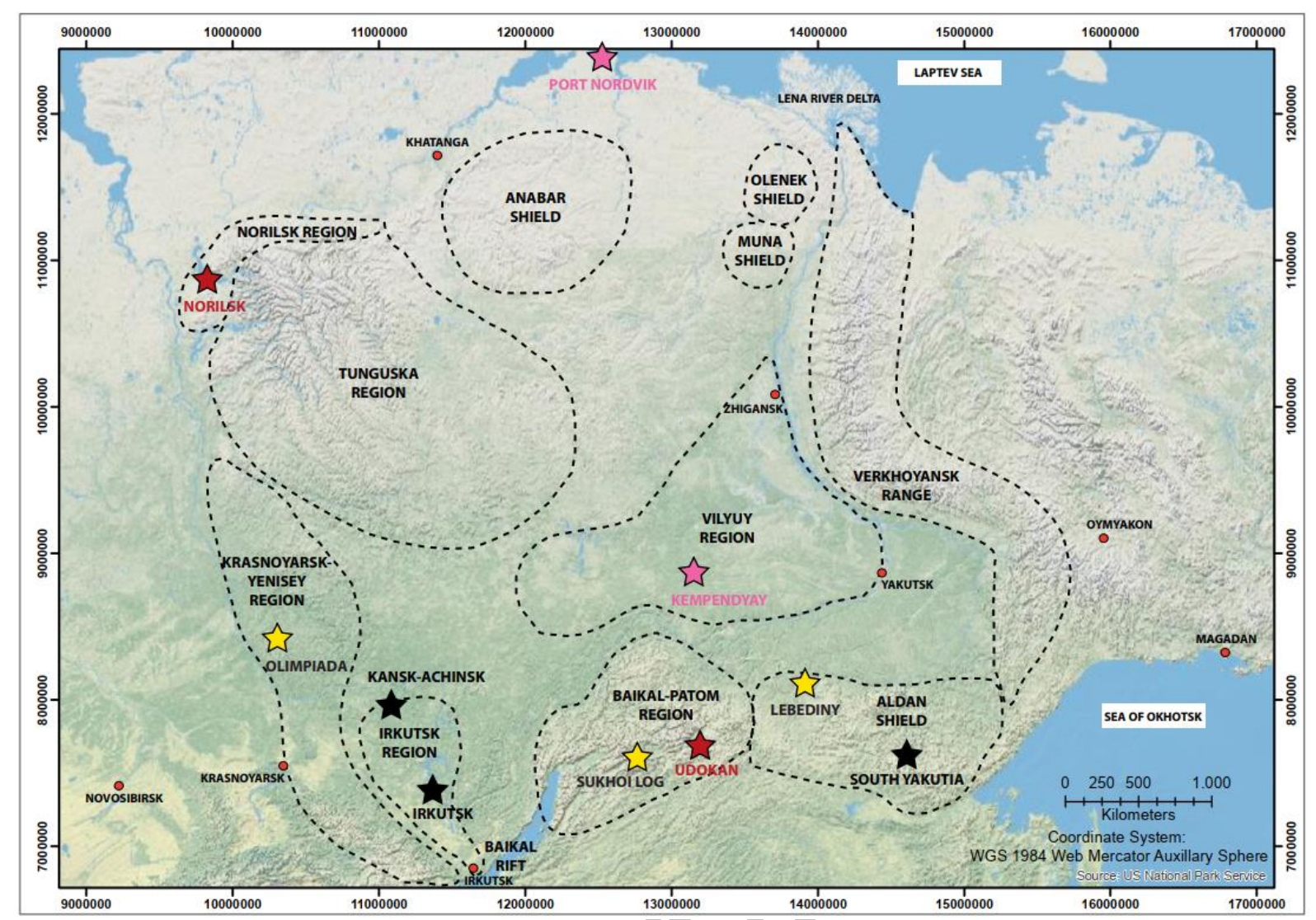

Figure 2. Prospective regions and selected gold (yellow), copper and PGE (red), coal (black), and evaporite (pink) mines of the Siberian Platform and adjacent ranges.

Figure 3 (following page). Petroleum Systems Charts for the Baykit High and NepaBotuoba regions, Siberian Platform, displaying the geological requirements and parameters to form a working hydrocarbon system. Of particular importance and scientific interest are the presence of Riphean source rocks. 
Petroleum Systems Chart of the Baykit High Region, Siberian Platform, Russia

\begin{tabular}{|c|c|c|c|c|c|c|c|c|c|}
\hline & \multicolumn{2}{|c|}{ Proterozoic } & \multicolumn{6}{|c|}{ Palaeozoic } & \multirow{2}{*}{$\begin{array}{c}\text { Mesozoic } \\
\text { Triassic }\end{array}$} \\
\hline & Riphean & Vendian & Cambrian & Ordovician & Silurian & Devonian & Carboniferous & Permian & \\
\hline \multicolumn{10}{|l|}{ Source Rock } \\
\hline & 00 & & & & & & & & \\
\hline & \begin{tabular}{c|c|} 
Gas & Oil/ \\
(deep) & Gas \\
\end{tabular} & & & & & & & & \\
\hline \multicolumn{10}{|l|}{ Reservoir } \\
\hline & 0 & & - & & & & & & \\
\hline \multicolumn{10}{|l|}{ Seal } \\
\hline & & & o & & & & & & \\
\hline $\begin{array}{c}\text { Trap } \\
\text { Formation } \\
\text { (stratigraphic } \\
\text { \& structural) }\end{array}$ & \multicolumn{2}{|c|}{ Stratigraphic } & 产 & & & Structural & & & \\
\hline $\begin{array}{l}\text { Timing of } \\
\text { Hydrocarbon } \\
\text { Generation }\end{array}$ & & & & & & & & & \\
\hline
\end{tabular}

Legend

= Marine clastic source rock

= Carbonate/ mixed carbonate-clastic source rock

= Coal/ Continental source rock

= Sandstone Reservoir

= Carbonate reservoir

= Shale seal

= Evaporite seal

= Oil window

= Gas window

= Proven productive/ effective source rock, reservoir or seal

Petroleum Systems Chart of the Nepa-Botuoba High Region, Siberian Platform, Russia

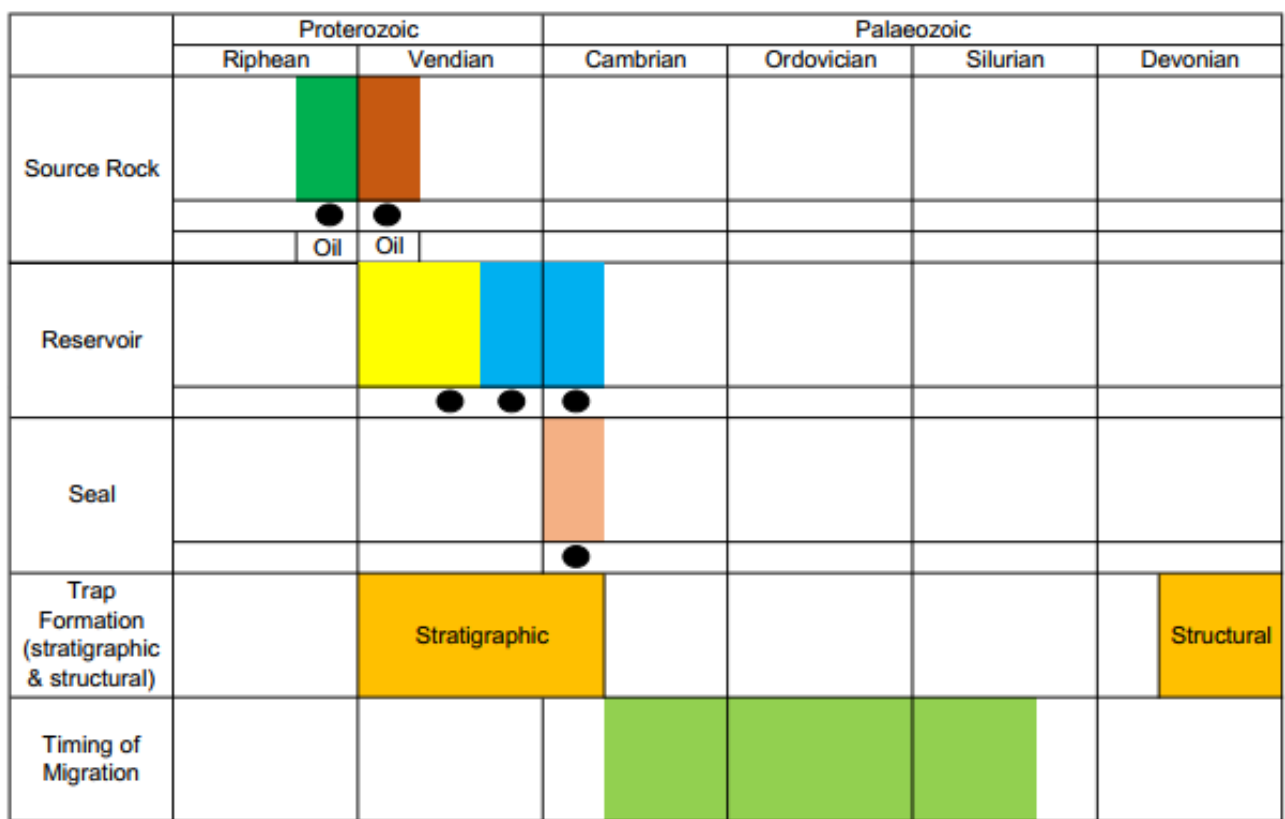

Legend

= Marine clastic source rock

= Carbonate/ mixed carbonate-clastic source rock

= Coal/ Continental source rock

= Sandstone Reservoir

= Carbonate reservoir

= Shale seal

= Evaporite seal

= Oil window

= Proven productive/ effective source rock, reservoir or seal 
Petroleum Systems Chart of the Lena-Vilyuy Basin, Siberian Platform, Russia

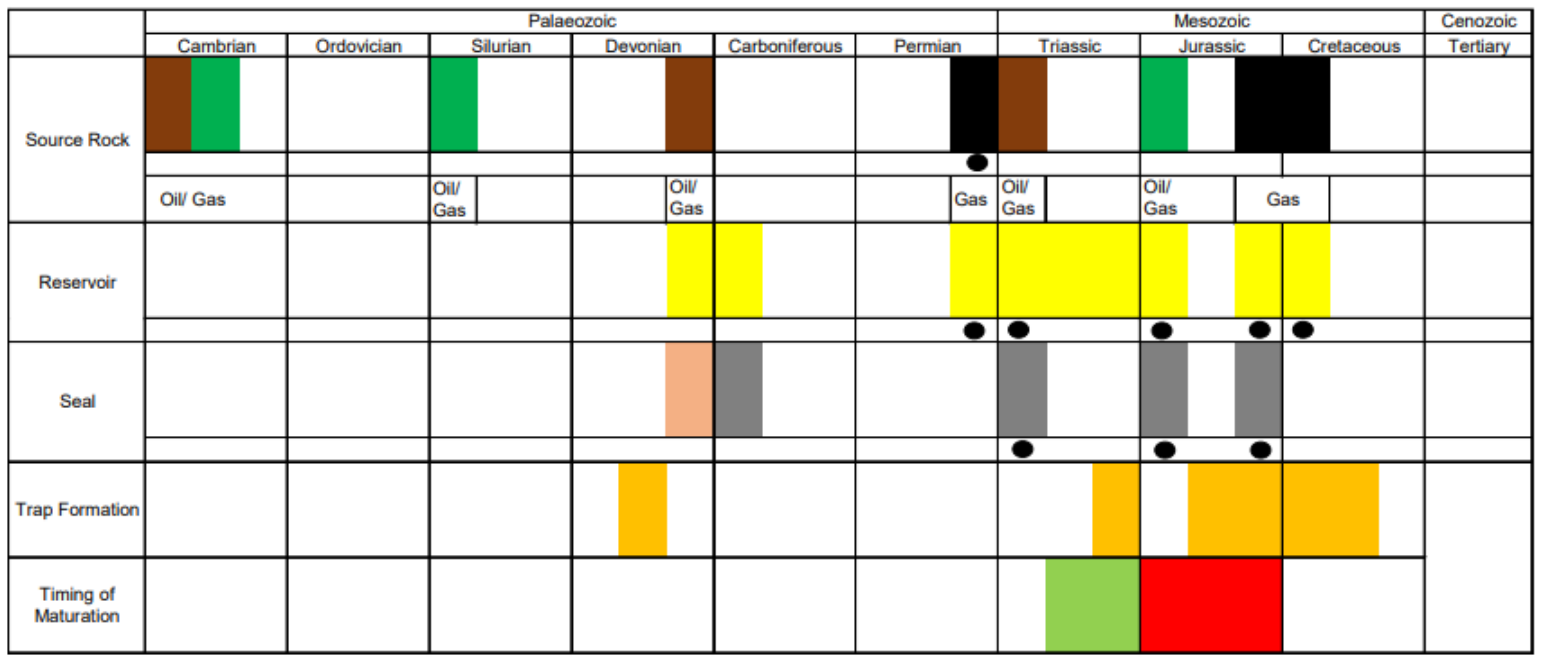

Legend $\quad=$ Marine clastic source rock

Carbonate/ mixed carbonate-clastic source rock

Coal/ Continental source rock

Sandstone Reservoir

E Shale seal

Evaporite seal

Oil window (proven late Permian source rock)

Gas window (proven late Permian source rock)

Proven productive/ effective source rock, reservoir or seal

Figure 4. Petroleum systems chart for the Lena-Vilyuy Basin and Vilyuy Depression, illustrating the temporal distribution of proven productive and potential source rocks, reservoirs, cap rocks and trapping structures. 